\title{
Archaeological Investigations and Oxidizable Carbon Ratio Dates from 41RK476, Rusk County, Texas
}

Mark Walters

Heritage Research Center, Stephen F. Austin State University

Follow this and additional works at: https://scholarworks.sfasu.edu/ita

Part of the American Material Culture Commons, Archaeological Anthropology Commons, Environmental Studies Commons, Other American Studies Commons, Other Arts and Humanities Commons, Other History of Art, Architecture, and Archaeology Commons, and the United States History Commons

Tell us how this article helped you.

This Article is brought to you for free and open access by the Center for Regional Heritage Research at SFA ScholarWorks. It has been accepted for inclusion in Index of Texas Archaeology: Open Access Gray Literature from the Lone Star State by an authorized editor of SFA ScholarWorks. For more information, please contact cdsscholarworks@sfasu.edu. 


\section{Archaeological Investigations and Oxidizable Carbon Ratio Dates from 41RK476, Rusk County, Texas}

\section{Creative Commons License}

\section{(c) (1) \&}

This work is licensed under a Creative Commons Attribution-NonCommercial 4.0 International License 


\title{
ARCHAEOLOGICAL INVESTIGATIONS AND OXIDIZABLE CARBON RATIO DATES FROM 41RK476, RUSK COUNTY, TEXAS
}

\author{
Mark Walters
}

\section{INTRODUCTION}

Volunteer survey work on a section of Rabbit Creek in Rusk County, Texas, found a possible buried midden deposit at 41RK476. This ongoing survey, which has resulted in 10 new sites being recorded, was conducted with the assistance of Bryan Boyd, also a member of the Texas Archeological Society and the Texas Archeological Stewards Network. Also aiding with shovel tests were Bo Nelson, Patti Haskins, Tim Perttula, and Bobby Gonzalez. Of particular interest in selecting this area for archaeological survey was the presence of protohistoric Caddo and historic Cherokee Indian groups that have been reported on Rabbit Creek (see Jones 1968). The creek derives its name from Chief Rabbit, a Cherokee chief.

With the landowner's permission a $1 \times 2 \mathrm{~m}$ test unit was placed at $41 \mathrm{RK} 476$ adjacent to a shovel test (ST 1) that indicated a possible midden deposit. This article reports the findings from this limited investigation, and includes a series of Oxidizable Carbon Ratio (OCR) dates financed by a grant from the Texas Archeological Society's Donor Fund.

\section{SETTING}

Briefly, 41 RK 476 is located on the south side of what has been termed the middle Sabine River basin on Rabbit Creek, a major tributary of the Sabine River that drains portions of Rusk and Gregg counties. The site is located on a toe slope rise, probably colluvial in nature, that is $1.2 \mathrm{~km}$ across a broad flat floodplain from Rabbit Creek. A small intermediate stream forms a natural boundary on two sides of the site (Figure 1) Behind the site the landform gradually rises to an upland terrace. Soils over most of 41 RK476 are a reddish-brown gravelly sandy loam overlying dark-red compact clay. Soils are thin on the margins and uphill portions of the site, with pockets of deeper soil on the mid-portions. Its current use is as an improved pasture with one pipeline right-of-way (Figure 2). There are also historical materials present in the upper levels from a historic house that was part of an early $20^{\text {th }}$ century oil camp.

\section{SCOPE OF WORK AND TECHNIQUES}

Twelve shovel tests were randomly placed across the landform (see Figure 2 and Appendix 1), and based on evidence recovered from ST 1 and ST 3, a $1 \times 2 \mathrm{~m}$ test unit was 

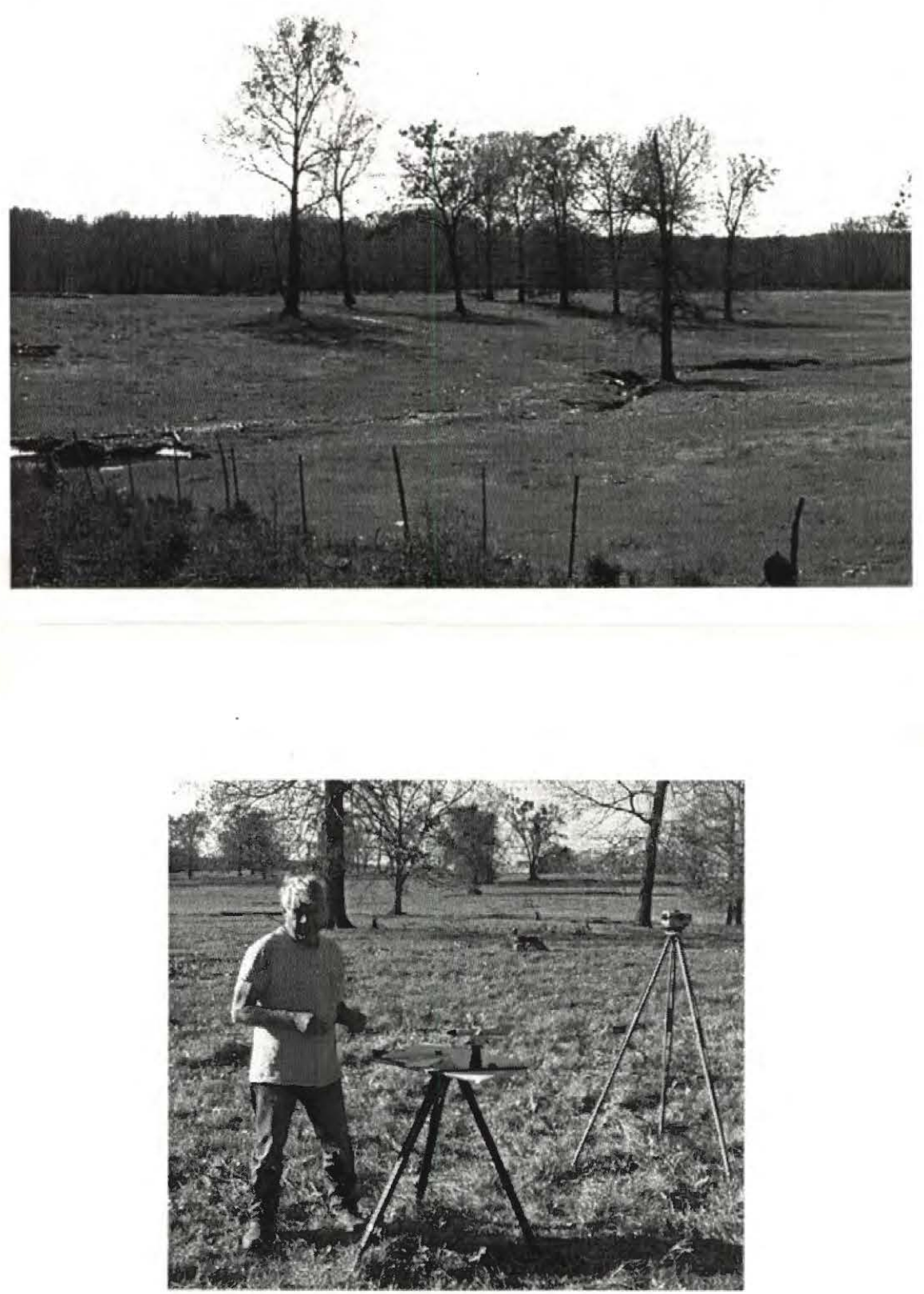

Figure 1. 41RK476: upper, Looking south at 41RK476; lower, general site area and mapping. 


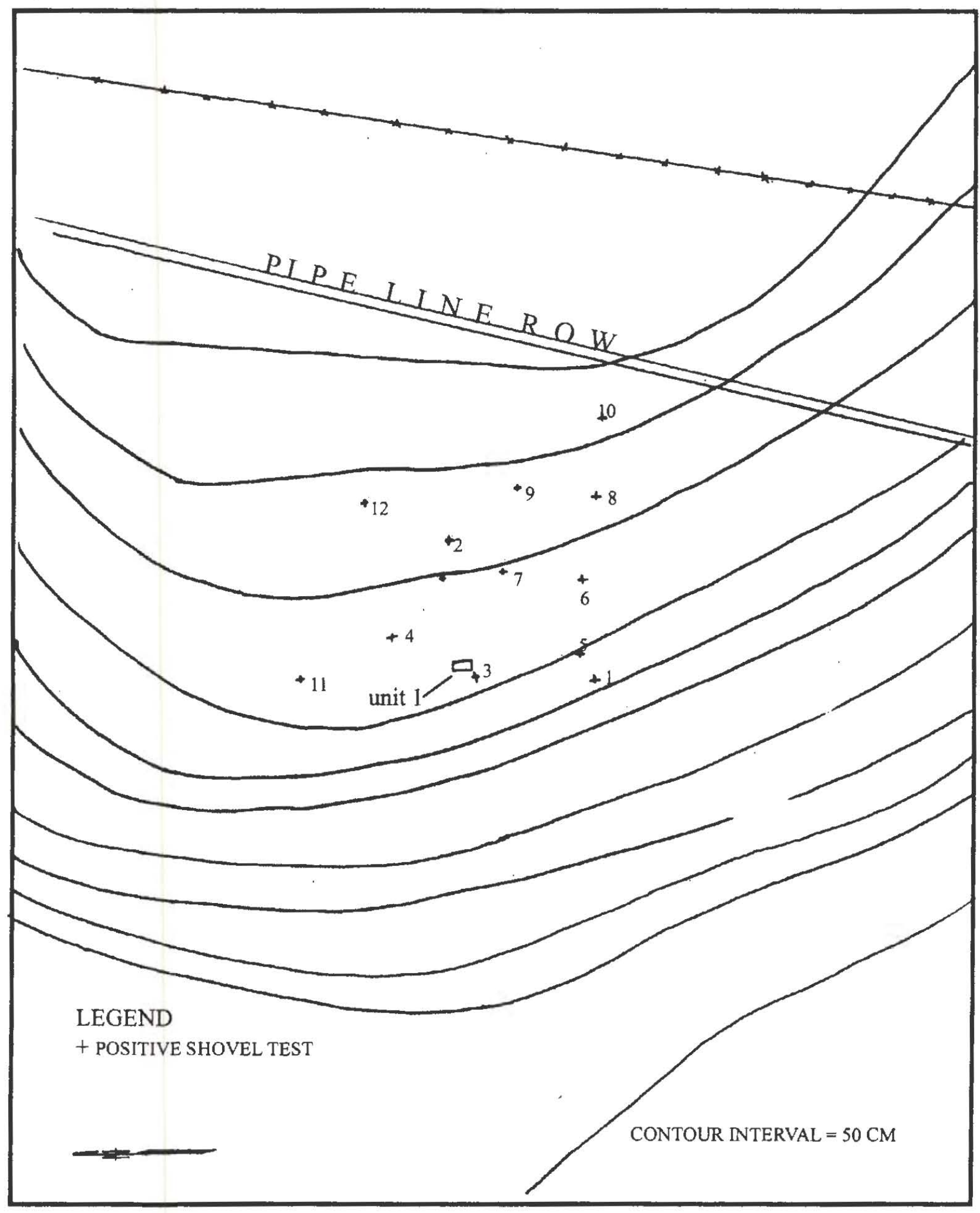

Figure 2. Shovel Tests and Unit 1 at 41 RK476. 
excavated in the western part of the site to recover more detailed information on the archaeological deposits there. The excavation was done in $10 \mathrm{~cm}$ arbitrary levels, with level sheets completed for each level, and the soil matrix was dry-screened through 1/4inch mesh for artifacts. Flat shovels were used to "shovel-shave" thin layers and levels were hand troweled for features, which were photographed and recorded on a separate feature form. A $20 \times 20 \times 10 \mathrm{~cm}$ soil sample was collected from Feature 1 at level 4 (30$40 \mathrm{~cm}$ below surface [bs]) for flotation. Upon reaching the sterile B-horizon clay soil, the west wall was cleaned, photographed and a profile drawn (Figure 3) and a column of soil samples for OCR dating was collected beginning at $10 \mathrm{~cm}$ bs (see OCR discussion below).

\section{DISCUSSION OF UNIT 1}

Level $1(0-10 \mathrm{~cm}$ bs) was a uniform dark yellowish-brown (10YR3/4) gravelly sandy loam (see Figure 3) with 100+ small sandstone fragments and pea-sized iron ore gravels. There was a disturbed area in the south end of the unit that consisted of a mixture of red clay, sand, and oil-dirt paving material probably associated with the old house site or past oil well construction.

Artifacts collected from level 1 include: 41 modem bottle glass pieces ( 33 brown, eight clear); 15 decorated prehistoric ceramic sherds, including two decorated rims; 44

plain body sherds, including one plain rim; one prehistoric ceramic pipe stem; and three lithic flakes.

Level $2(10-20 \mathrm{~cm} \mathrm{bs})$ was dark brown (10YR3/3) on the north end of the unit and dark yellowish-brown (10YR4/4) on the south half, with a $25 \mathrm{~cm}$ wide wedge of dark yellowish-brown (10YR 3/6) soil extending from the west wall in the middle of the unit. There were small red clay mottles and flecks of charcoal scattered throughout. Artifacts from level 2 included: eight modern bottle glass pieces (six brown, two clear); 25 decorated prehistoric ceramic sherds, including seven decorated rims; 74 plain sherds, including two plain rims; and six lithic flakes.

Level $3(20-30 \mathrm{~cm}$ bs) soils contained more gravel $(200+)$ and had flecks of charcoal and red clay mottles (see Figure 3). A very dark brown (10YR2/2) area of soil extending from the west wall was designated Feature 1. The remaining soil matrix yielded the following artifacts: 40 plain prehistoric ceramic sherds, including one rim; 14 decorated sherds, including one decorated rim; six lithic flakes; and one unidentified bone fragment.

Level 4 (30-40 cm bs) ended at red sandy clay (2YR4/8) (see Figure 3). Feature 1 was composed of very dark brown (10YR2/2) soil sloping east-west to red clay in the middle of the unit (see Figure 3). As previously mentioned, a $20 \times 20 \times 10 \mathrm{~cm}$ sample was collected for flotation from the feature. At the base of Feature 1, extending into a slight depression in the red clay, was a shallow lens of small washed gravel and layers of silt. 


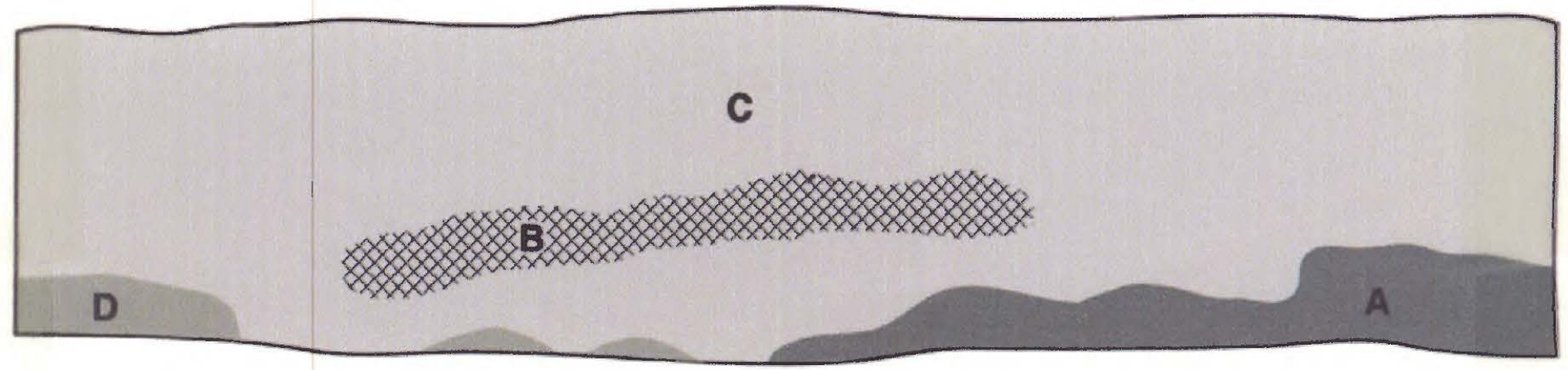

\section{A 7.5 YR 4/6 STRONG BROWN}

B 10 YR 2/2 VERY DARK BROWN

$\square$ C 10 YR 3/4 DARK YELLOWISH BROWN

$\square$ D 2.5 YR 4/8 RED

\begin{tabular}{l|l|} 
Rabbit Creek 41 R476 & $\begin{array}{c}10 \mathrm{~cm} \\
\text { scale }\end{array}$ \\
Test Unit \#1 \\
$\begin{array}{l}5-6-00 \\
\text { BB }\end{array}$
\end{tabular}

Figure 3. Profile of Unit 1, west wall. 
The interpretation based on the west wall profile (see Figure 3) was that Feature 1 represented a prehistoric gully of unknown date or origin that had been eroded down to the red subsoil clay, following the natural slope, and then was used for refuse disposal during the Caddo occupation.

Artifacts from level 4 were: 20 plain prehistoric ceramic sherds; 11 decorated body sherds; one pipe stem fragment; one arrow point; one unidentified bone fragment; one chunk of charred wood; and two lithic flakes.

\section{PREHISTORIC CERAMICS}

The ceramic assemblage from 41 RK476 totaled 274 prehistoric ceramic sherds, including 75 decorated and 199 plain pieces. The plain/decorated sherd ratio is 2.65 . More than $27 \%$ of the sherds were decorated (Table 1) The average sherd thickness was $7.03 \mathrm{~mm}$, ranging from $6.75 \mathrm{~mm}$ for the decorated sherds, and 7.30 for the plain sherds. The types and amounts of temper in the sherds are listed in Table 2. Pieces of bone and grog or grog were the preferred tempers in the 4IRK476 ceramics.

Table 1. Decorated Sherds from 41RK476.

TYPE N Incised Punctated Engraved Red-Slipped Punctated/Incised Brushed A-P-B

\begin{tabular}{|c|c|c|c|c|c|c|c|}
\hline Rim & 13 & $5(38.5)^{*} 7(53.8)$ & $1(7.7) 0$ & 0 & 0 & 0 & 0 \\
\hline Body & 62 & $25(40.3) 17(27.4)$ & $7(11.3)$ & $1(1.6)$ & $7(11.3)$ & $4(6.5)$ & $1(1.6)$ \\
\hline Total & 75 & $30(40.0) 24(32.0)$ & $8(10.7)$ & $1(1.3)$ & $7(9.3)$ & $4(5.3)$ & $1(1.3$ \\
\hline
\end{tabular}

*Number/Percentage $\quad \mathrm{A}-\mathrm{P}-\mathrm{B}=$ appliqued-punctated-brushed

Table 2. Temper Analysis for 41 RK476 Sherds.

\begin{tabular}{llllll}
\hline TYPE & N & Bone/Grog & Grog & Bone/Grog/Grit & Grog/Grit* \\
\hline $\begin{array}{llllll}\text { Decorated Sherds } \\
\text { Plain Sherds }\end{array}$ & $\begin{array}{l}75 \\
199\end{array}$ & $\begin{array}{l}49(65.3)^{* *} \\
134(67.3)\end{array}$ & $\begin{array}{l}16(21.3) \\
56(28.1)\end{array}$ & $\begin{array}{l}4(5.3) \\
7(3.5)\end{array}$ & $\begin{array}{l}6(8.0) \\
2(1.0)\end{array}$ \\
\hline Total & 274 & $183(66.8)$ & $72(26.3)$ & $11(4.0)$ & $8(2.9)$ \\
\hline
\end{tabular}

* grit denotes finely ground hematite

**Number/Percentage 


\section{Incised Sherds}

Incising was the favored method of decoration (40\%). Table 1 indicates that incised designs were fairly consistent on both body and rim sherds; however, crosshatching and parallel diagonal design elements were more common on rim sherds (Figure $4 a, c)$. Single straight incised lines were the most common decoration but this could be a factor of sherd size. There were seven sherds each that displayed opposing straight lines or parallel straight lines (see Figure $4 b$ ). There were two curved incised line elements and two curved with opposing straight line designs. One sherd had an untyped meander design.

\section{Punctated Sherds}

Various methods of punctation accounted for $32 \%$ of all the decorated sherds (see Table 1). Some form of punctation was the most common design element on rims $(n=7$, $53 \%$ ) (Figure 5c), but punctations were only present on $17(27.4 \%)$ of the decorated body sherds. This is a characteristic of Caddo ceramics, in that they used different elements on the body and rim. Some type of instrument formed most of the punctated techniques practiced at $41 \mathrm{RK} 476$, with certainty, even those that were "fingernail-like" in appearance. The choice of instrument resulted in mostly large gouge marks (37.5\%) formed randomly by a blunt instrument. Four sherds had random slash punctates, which was really more of an elongated puncture. Punctates in rows occurred on two body sherds and there were four with semi-circular fingernail-like punctates. The remaining five sherds had small random circular punctates.

\section{Engraved Sherds}

The engraved elements were uncomplicated compared to other Caddo ceramic assemblages in the middle Sabine River basin. Eight (10.7\%) of the decorated sherds were engraved, including one rim (7.7\%) with horizontal parallel lines (see Figure 5a). Three had single straight lines (one was from a bottle) and three have straight parallel lines. The remaining engraved sherd had an element composed of opposing straight lines (see Figure $5 b$ ). No pigment smeared in the lines was noted on any of the engraved sherds.

\section{Punctated/Incised Sherds}

Very few combinations of design techniques were noted in the punctated/incised sherds. There were seven $(9.3 \%)$ body sherds with some combination of incised lines and punctates. Five sherds had design elements composed of curvilinear lines enclosing zones of punctates. One zone contained both triangular and round punctates (Figure 6a) Two sherds had neat rows of diagonal punctates bordered by a single straight line (see Figure $6 c$ ). 


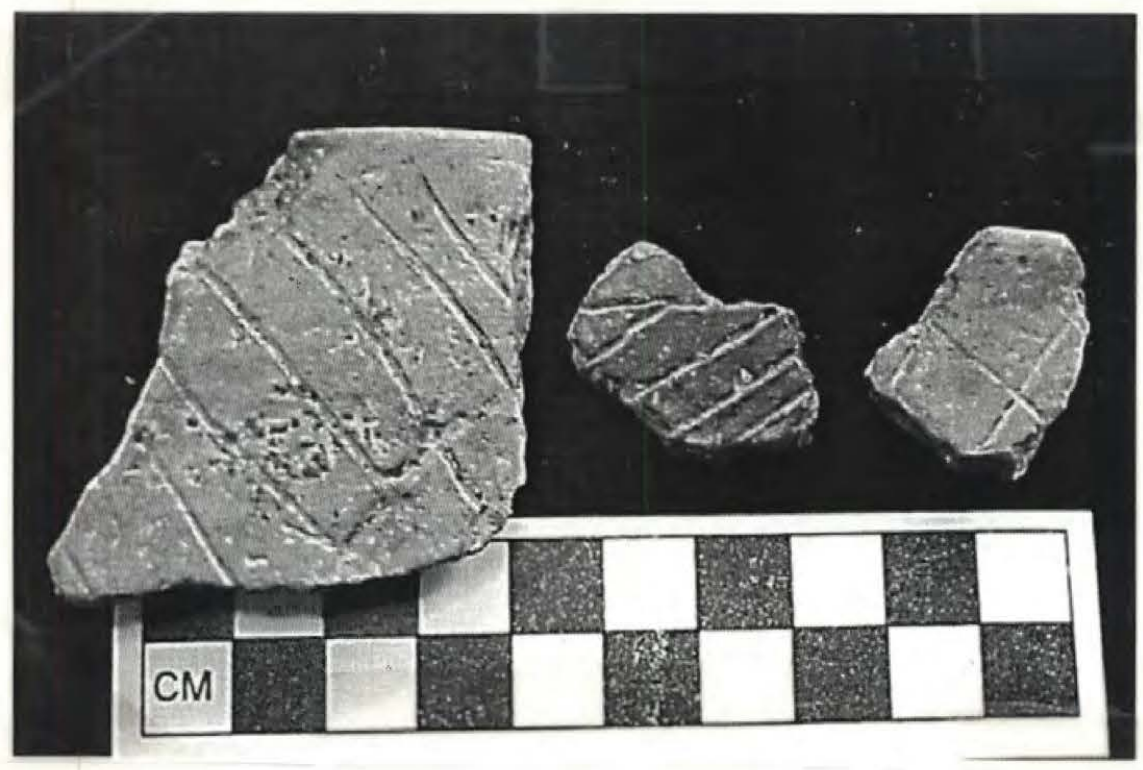

Figure 4. Incised Sherds: a, c, rim sherds; b, body sherd.

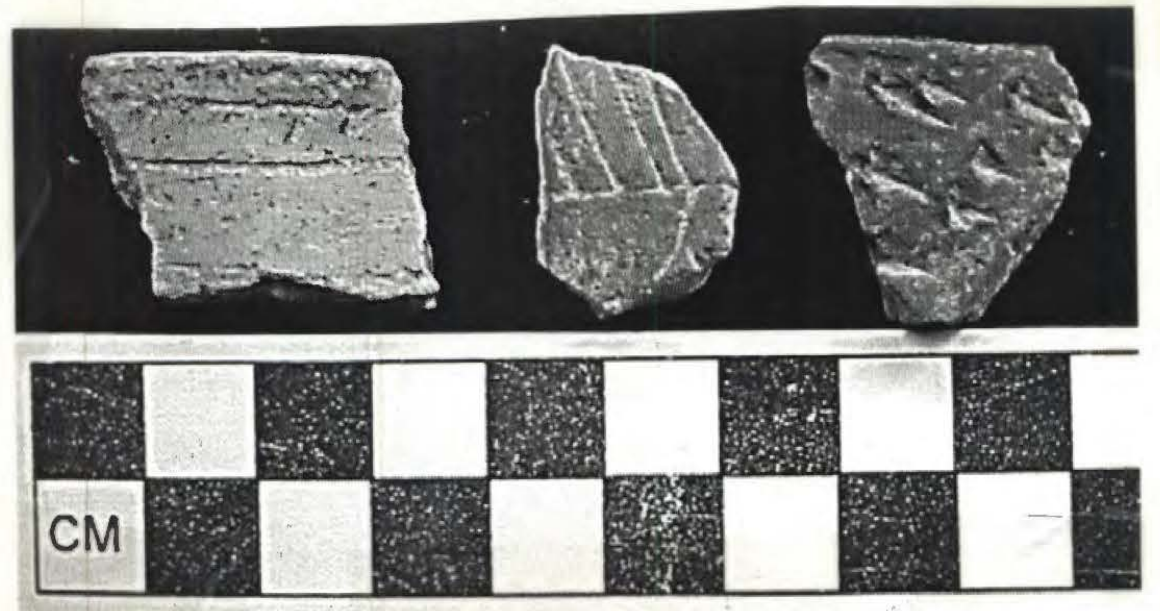

Figure 5. Engraved and Punctated sherds: a, engraved rim; b, engraved body; $c$, punctated rim.

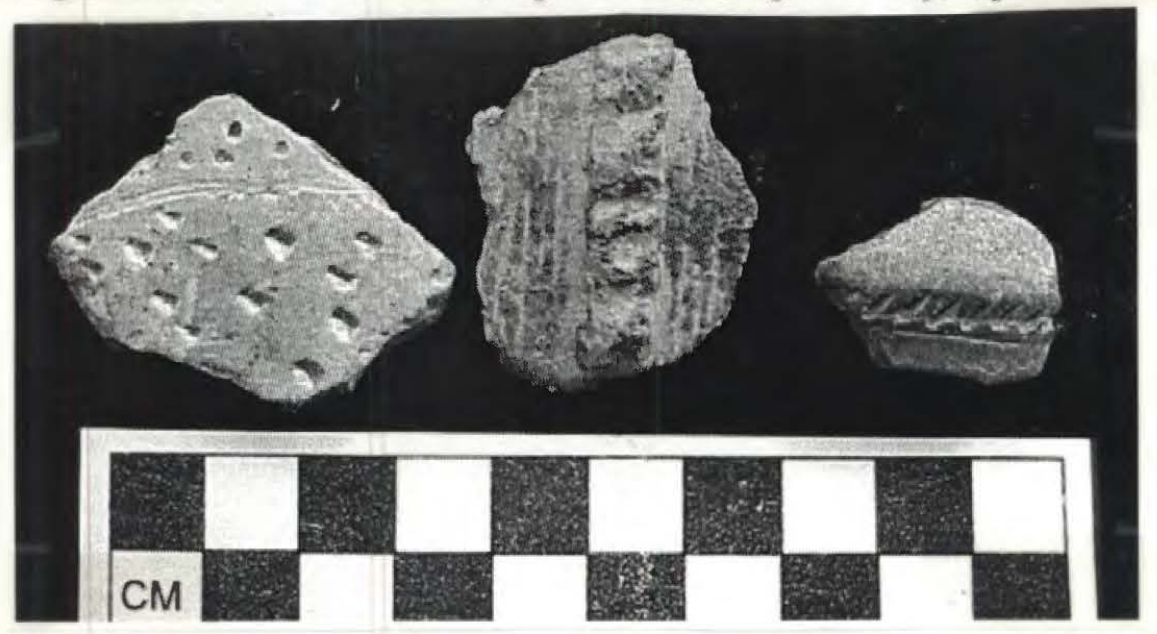

Figure 6. Punctated/Incised and Brushed-punctated-appliqued sherds: a, c, punctated incised; b, brushedpunctated-appliqued. 


\section{Brushed Sherds}

Only $4(6.5 \%)$ of the decorated sherds were brushed, and this decoration was marked by faint crisscrossing brushing probably made with a bundle of stiff grass. All four brushed sherds were body sherds.

\section{Appliqued/Brushed/Punctated}

There was one (1.3\%) body sherd in Unit $1(20-30 \mathrm{~cm}$ bs) that had vertical brushing separated by a vertical row of appliqué with punctates (see Figure 6b). The decoration is typical of examples of Pease Brushed-Incised (Suhm and Jelks 1962:19-20).

\section{Red-Slipped}

One (1.3\%) red-slipped sherd was included in the decorated sherds because it was felt that it represented a conscious effort to enhance an artifact, i.e., to decorate it. The red-slipped sherd was recovered from ST 2, 0-20 cm bs, and had a dark red exterior surface that was partially eroded. The temper was bone-grog, and it had been fired in a reduced atmosphere and then allowed to cool in a high oxygen atmosphere (see Teltser 1993). The scarcity of red-slipped sherds in the middle Sabine River basin has been noted in other studies (see Perttula and Cruse 1997).

\section{Rim Forms}

Of the 13 decorated rims, 10 were direct and three were everted. Five others were thinned. There were 10 round lips and three with flat lips. There were also four plain rims. Two were direct with round lips and one was direct with a flat rim. The remaining sherd was $3.8 \mathrm{~mm}$ thick, and had an inverted rim that was slightly folded to the inside.

\section{OXIDATION PATTERNS IN THE 41RK476 CERAMICS}

An attempt to analysis firing conditions of the 274 ceramic sherds from 41 RK 476 was made with the hope of noting differences between different classes of ceramics and to provide a means of comparing ceramics from comparable sites in the region. Using guidelines outlined by Patrice A. Teltser (1993) for low-fired ceramics, it was determined that 108 sherds $(39.4 \%$ ) had been fired in a low oxygen (reduced) environment and also cooled in a reduced environment. Another $116(42.3 \%)$ sherds had been fired in a reduced environment then cooled in a high oxygen environment. The remaining 50 (18.2\%) sherds indicate that they had been fired in a high oxygen or oxidizing environment, where carbon can be burned off more readily, and this is evidenced by the sherd cores having uniform light brown and orange colors.

Looking at the differences between plain and decorated sherds in the 41RK476 assemblage, 75 decorated sherds $(76 \%)$ had been fired in a reduced atmosphere and $24 \%$ were fired in a high oxygen atmosphere. This compares closely to the plain sherds, with 
$84 \%$ fired in a reduced atmosphere and $16 \%$ in a high oxygen atmosphere. There is not a great difference between the number of decorated and plain sherds fired in low versus high atmospheres, but comparing how the reduced sherds were cooled, $50.8 \%$ of the plain reduced sherds were cooled in a high oxygen atmosphere while only $20 \%$ of the decorated sherds were cooled in a high oxygen atmosphere. Whether this was a conscious effort on the part of the potters that had meaning that can be measured in future studies is a question that can only be answered by comparison with other assemblages.

\section{CERAMIC CLAY PIPES}

Two stem fragments from long-stemmed Red River style pipes were recovered from Unit 1 (Figure 7). These appear to be from Early Caddoan Miller's Crossing and/or Graves Chapel varieties (Hoffman 1967). Stem fragment one is from level 1 and is 13.8 $\mathrm{mm}$ in length and the diameter is $13.7 \mathrm{~mm}$. The stem hole is $4.6 \mathrm{~mm}$ in diameter. Stem fragment two, from level 4, is $18.6 \mathrm{~mm}$ long and the diameter is $11 \mathrm{~mm}$ with a stem hole diameter of $4.3 \mathrm{~mm}$. Temper of both fragments was bone/grog.

\section{FIRED CLAY}

Bits $(n=48)$ of bright orange fired clay pieces, $9 \mathrm{~mm}$ and smaller, were collected from the following locations: Feature 1, heavy-fraction, $30-40 \mathrm{~cm}(\mathrm{n}=6)$; OCR sample Unit $1,35 \mathrm{~cm}$ bs $(\mathrm{n}=10)$; and OCR sample Unit $1,40 \mathrm{~cm}$ bs $(\mathrm{n}=32)$.

\section{LITHIC ARTIFACTS}

Thirty-seven lithic artifacts were found in the 41RK476 investigations. They consisted of four secondary flakes, 27 interior flakes (which include 12 tiny retouch flakes from Feature 1, heavy fraction), three worked flakes, and three projectile points (Figure 8). Most of the assemblage came from red, tan, black, and gray (with white flecks) cherts. No petrified wood artifacts were noted, although this raw material is present in the vicinity. The raw material source for the lithic assemblage is not known, though small workable cobbles are present on terraces along the Sabine River.

The lack of obvious exotic materials suggests there was no far-reaching exchange, indicating that most trade was with local groups in the immediate vicinity. Although the sample size from 41 RK476 was very limited, the lack of primary flakes, cores, and hammerstones implies that tool manufacture was absent at the site and activity was limited to tool maintenance.

Two flakes from Unit 1 ( $20-30 \mathrm{~cm}$ bs) showed signs of edge modification. One, of a light tan chert, had four flake scars along one margin. The other, a black chert flake with white flecks, was bipointed from possible bipolar reduction (see Girard 1995), and had retouch flake scars along one margin. 


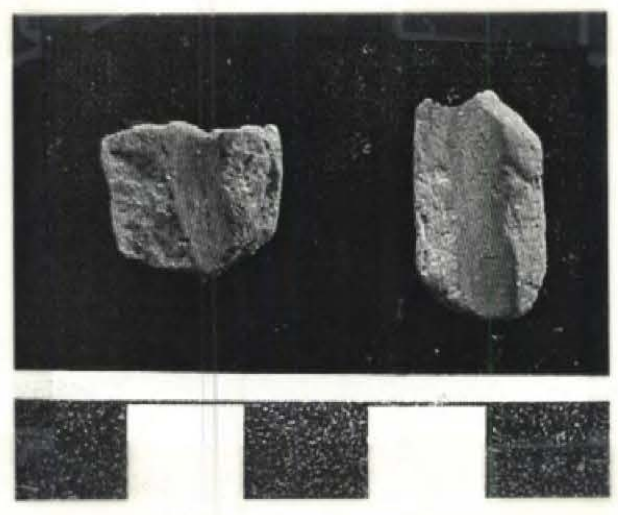

Figure 7. Pipe stem sherds from 41RK476.
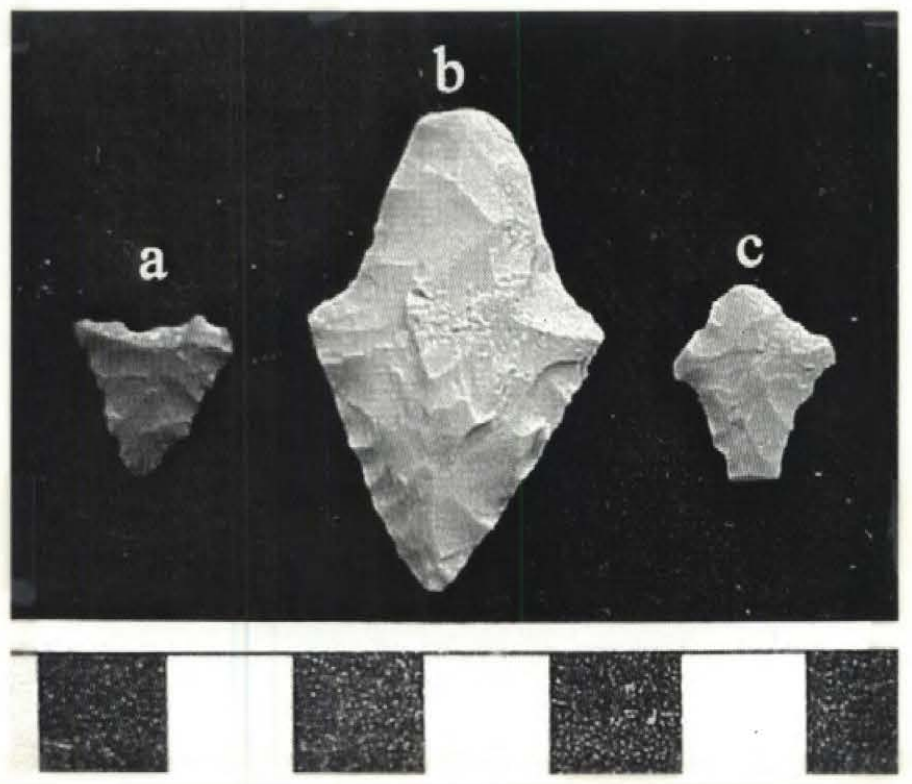

Figure 8. Projectile points: a, c, arrow points; b, Gary, var. Camden dart point. 
Also classified as a tool was a $2 \mathrm{~cm}$ long piece of tan siltstone with red cortex. The removal of two large flakes produced a sharp edge. Its use is unknown, but one surface showed evidence of polishing, possibly from plant or hide processing.

Three projectile points were recovered from 41RK476. One arrow point from Unit $1(30-40 \mathrm{~cm}$ bs) was made from a tan chert and was $15.1 \mathrm{~mm}$ long, $12.7 \mathrm{~mm}$ wide, and $2.5 \mathrm{~mm}$ thick (see Figure $8 \mathrm{c}$ ) The untyped point had concave lateral edges, prominent barbs, and a bulbous stem. The second arrow point was from ST $5(20-33 \mathrm{~cm}$ bs) and was made from red chert (see Figure 8a). The stem was missing and the remaining length was $11 \mathrm{~mm}$, with a width of $12.3 \mathrm{~mm}$, and it was $3.8 \mathrm{~mm}$ thick. The third point was a well made Gary var. Camden (Schambach 1998) dart point made from tan chert (see Figure 8b). Cortex was present on the tip of the stem. Dimensions were: length 37.1 $\mathrm{mm}$, width $22.8 \mathrm{~mm}$, and it was $8 \mathrm{~mm}$ thick. The stem was $12.6 \mathrm{~mm}$ long and $13.5 \mathrm{~mm}$ wide.

\section{CHARRED FLORAL REMAINS}

Charred, as yet unanalyzed material, was collected from the following locations: ST 3, 0-20 cm bs, one possible charred nut shell; Unit $1,30-40 \mathrm{~cm}$ bs, one unidentified charred plant material; OCR sample, $10 \mathrm{~cm}$ bs, three bits of unidentified charred plant material; OCR sample, $15 \mathrm{~cm}$ bs, six unidentified charcoal bits; OCR sample, $25 \mathrm{~cm}$ bs, one unidentified charcoal; and Feature 1, fine-screen, $30-40 \mathrm{~cm}$ bs, unidentified charred material.

\section{FAUNAL REMAINS}

The following unidentified bone fragments were recorded: ST $10-20 \mathrm{~cm}$ bs, one bone fragment (20.4 mm long, $11.8 \mathrm{~mm}$ wide); Unit $120-30 \mathrm{~cm}$ bs, one bone fragment (19.5 mm long, $12.1 \mathrm{~mm}$ wide); Unit $130-40 \mathrm{~cm}$ bs, one burned bone fragment $(9 \mathrm{~mm}$ long, $8.6 \mathrm{~mm}$ wide); OCR sample $25 \mathrm{~cm}$ bs, one bone fragment ( $3 \mathrm{~mm}$ in length and width); and Feature 1 heavy fraction, $30-40 \mathrm{~cm}, 11$ small unidentified bits of bone.

\section{OXIDIZABLE CARBON RATIO (OCR) DATES}

Funds for the OCR dates came from a grant from the Texas Archeology Society's Donors Fund. In an effort to learn the age of Feature 1 and the surrounding soils a column of soil samples was collected at $5 \mathrm{~cm}$ levels (beginning at $10 \mathrm{~cm} \mathrm{bs}$ ) from the west wall of Unit 1 for OCR dating (for more information see the OCR Carbon Dating home page at (http://members.aol.com/dsfrink/ocr/ocrpage.htm). It was hoped that a series of dates could explain how and when Feature 1 was formed and provide associated dates for the ceramics. More absolute dates are urgently needed from tight contexts in Northeast Texas archeological sites before we can begin to answer the "who, what, where and when" questions. 
As with other dating techniques proper sampling has much to do with the final outcome. Beginning at $10 \mathrm{~cm}$ bs a series of samples were collected at $5 \mathrm{~cm}$ intervals, and extending to red clay below Feature 1 at $40 \mathrm{~cm}$ bs (Table 3).

Table 3. OCR Dating Results.

\begin{tabular}{|c|c|c|c|c|c|c|c|c|c|c|c|c|c|}
\hline Soil Depth & $\mathrm{pH}$ & \%Onganic Ca & Ocr Date & Nory Coarsel & Coarse & Modium & Fine & Very Fine $k$ & Coarse Silt & Fine Silt 5 & Sample 1 & Xoxidleable Carto & OCR_Ratio \\
\hline 10 & 4.5 & 1.703 & 273 & 3.17079 & 1.64097 & 1.04091 & 6.63222 & 40.37385 & 35.98943 & 11.15183 & 4892 & 0.54 & 3.15370348 \\
\hline 15 & 49 & 1.088 & 355 & 3.83124 & 1.36123 & 81412 & 529106 & 4368966 & 31.99514 & 1201755 & 4893 & 0.5 & 2.17600012 \\
\hline 20 & 4.8 & 0.949 & 561 & 3.37594 & 1.18427 & 82899 & 6.38429 & 39.996 & 34.19078 & 1403974 & 4894 & 0.25 & 3.79600000 \\
\hline 25 & 48 & 0.988 & 700 & 6.11191 & 1.31226 & .70211 & 6.19427 & 42.26036 & 30.24446 & 13.17452 & 4895 & 0.33 & 2.99393920 \\
\hline 30 & 4.8 & 1.137 & 806 & 1.80534 & 1.10636 & .67731 & 6.10499 & 40.16812 & 35.64853 & 14.48935 & 4896 & 0.46 & 247173901 \\
\hline 35 & 4.7 & 0.904 & 964 & 2.73131 & .9759 & 73127 & 7.08737 & 44.15685 & 31.45342 & 12.86388 & 4897 & 0.3 & 3.01333316 \\
\hline 40 & 4.6 & 0.971 & 1091 & 11.53056 & 2.31454 & 1.31958 & 9.2458 & 42.25662 & 23.6087 & 9.72221 & 4898 & 0.32 & 3.03437512 \\
\hline
\end{tabular}

Douglas Frink (personal communication 2000) states that the OCR data indicated two principal pedogenic events that are consistent with deposition. One of these events (broadly defined, but it may consist of a series of individual events at a smaller scale) falls within the time range of 561-700 YBP or A.D. 1250-1389. The other falls within the time range of 964-1092 YBP (A.D. 858-986).

A hypothesized sequence of events proposed based on the OCR dates is that the erosional feature (ditch) occurred sometime prior to A.D. 858 and slowly reached equilibrium by A.D. 986. Caddo use of this soil body commenced sometime after A.D. 1250 and lasted up till around A.D. 1389 (see Appendix 2) There is the possibility that older organic matter from the underlying and slope sides of the ditch were incorporated in the lower midden soils; however, according to Frink (personal communication 2001) the influence of such on the age estimate provided by the OCR analyses is not likely to have been significant. The majority of the artifacts came from the $20-30 \mathrm{~cm}$ level (with OCR dates ranging between A.D. 1144-1389), and this was probably the period of most intense use of 41 RK 476. The floor plan at $20 \mathrm{~cm}$ bs and the west wall profile confirm that the ditch had reached equilibrium and the present ground surface sediments were in place by modern times. 


\section{DISCUSSION}

Limited testing at 41 RK476 indicated that it was a small Caddo homestead consisting of one or two houses and an associated midden area. The small size of the landform limits any significant habitation, and shovel tests, other than the small midden discovered in ST 3, suggest a light occupation. The artifacts, other than a Gary dart point in ST 8, are also indicative of a single, probably short-term occupation.

The ceramics, with the exception of four brushed sherds and one Pease-BrushedIncised sherd, more closely fit Early Caddoan-style Alto phase examples. Engraved sherds consist of horizontal parallel lines similar to Hickory Fine Engraved and opposing parallel straight lines similar to Holly Fine Engraved, but the latter lacks the precision of work or required excised areas (see Suhm and Jelks 1962). With over $90 \%$ of the decorated sherds belonging to only four styles (incised, punctated, engraved, and punctated/incised) and over $75 \%$ composed of incised and punctated designs, 41 RK476 clearly fails to meet the stylistic diversity that define many Middle Caddoan period sites, especially in the Sabine and Angelina River basins (see Middlebrook and Perttula 1997) Rather, the ceramic assemblage more closely resembles the chronological and ceramic data set forth by Maynard B. Cliff (1997) for the Middle Caddoan period in the Lower Sulphur River area as representing more "isolated social groups."

\section{REFERENCES CITED}

Cliff, M. B.

1997 The Middle Caddoan Period in the Lower Sulphur River Area. Journal of Northeast Texas Archaeology 9:9-16.

Girard, J. S.

1995 The Chipped Stone Collection: Technological, Functional, and Typological Analyses. In The Deshazo Site, Nacogdoches County, Texas, Volume 2: Artifacts of Native Manufacture, edited by D. A. Story, pp. 33-156. Studies in Archeology 21.Texas Archeological Research Laboratory, The University of Texas at Austin.

Hoffman, M. P.

1967 Ceramic Pipe Style Chronology Along the Red River Drainage in Southwestern Arkansas. The Arkansas Archeologist 8 (1):4-14.

Jones, B. C.

1968 The Kinsloe Focus: A Study of Seven Historic Caddoan Sites in Northeast Texas, Master's thesis, Department of Anthropology, University of Oklahoma, Norman. 
Middlebrook, T. and T. K. Perttula

1997 The Middle Caddoan Period in East Texas: A Summary of the Findings of the East Texas Caddoan Research Group. Journal of Northeast Texas Archaeology 9:1-8.

Perttula, T. K. and J. B. Cruse

1997 The Caddoan Archaeology of the Sabine River Basin during the Middle Caddoan Period. Journal of Northeast Texas Archaeology 9:30-37.

Schambach, F. F.

1998 Pre-Caddoan Cultures in the Trans-Mississippi South: A Beginning Sequence. Research Series 53. Arkansas Archeological Survey, Fayetteville.

Suhm, D. A. and E. B. Jelks (editors)

1962 Handbook of Texas Archeology: Type Descriptions: Initial Series of Descriptions. Special Publication No. 1, Texas Archeological Society, and Bulletin No. 4, Texas Memorial Museum, Austin.

Teltser, P. A.

1993 An Analytic Strategy for Studying Assemblage-Scale Ceramic Variation: A Case Study from Southeast Missouri. American Antiquity 58(3):530-543. 


\section{Appendix 1, Shovel Test Descriptions}

ST $1 \quad 0-15 \mathrm{~cm}$, brown sandy loam; $15-27 \mathrm{~cm}$, dark brown sandy loam; $27-40 \mathrm{~cm}$, very dark brown sandy loam; $40 \mathrm{~cm}+$, red clay. $0-20 \mathrm{~cm}, 3$ sherds, 1 modern bottle glass; 20 $40 \mathrm{~cm}, 5$ sherds, 1 bone.

ST $20-25 \mathrm{~cm}$, dark brown sandy loam; $25-40 \mathrm{~cm}$, reddish-brown sandy loam; $40 \mathrm{~cm}+$, red clay. $100+$ pea-sized iron ore gravels (IOG). $0-20 \mathrm{~cm}, 3$ sherds.

ST $3 \quad$ 0-30 cm, dark brown sandy loam; $30-45 \mathrm{~cm}$, reddish-brown sandy loam; $45 \mathrm{~cm}+$, red clay. $100+$ pea-sized IOG. $0-20 \mathrm{~cm}, 3$ sherds; 1 charcoal, 2 modern bottle glass.

ST $4 \quad$ 0-12 cm, dark brown sandy loam; 12-25 cm, reddish-brown sandy loam; $25 \mathrm{~cm}+$, red clay. $100+$ pea-sized IOG. $0-20 \mathrm{~cm}, 4$ sherds.

ST $5 \quad$ 0-27 cm, reddish-brown gravelly loam; $27-33 \mathrm{~cm}$, light reddish-brown gravelly loam. $200+$ pea-sized IOG. $0-20 \mathrm{~cm}, 2$ sherds; $20-33 \mathrm{~cm}, 1$ arrow point.

ST $6 \quad 0-25 \mathrm{~cm}$, reddish-brown sandy loam; $25-35 \mathrm{~cm}$, light reddish-brown sandy loam. 200+ pea-sized IOG. $0-20 \mathrm{~cm}, 1$ lithic tool.

ST $7 \quad 0-32 \mathrm{~cm}$, dark brown sandy loam; $32-48 \mathrm{~cm}$, light reddish-brown sandy loam; 48 $\mathrm{cm}+$, red clay. $200+$ pea-sized IOG. $0-20 \mathrm{~cm}, 2$ sherds.

ST $8 \quad 0-9 \mathrm{~cm}$, brown gravelly sandy loam; $9-19 \mathrm{~cm}$, light reddish-brown gravelly loam; $19 \mathrm{~cm}+$, red clay. $200+$ pea-sized IOG. 0-19 cm, 1 dart point (Gary).

ST $90-22 \mathrm{~cm}$, dark brown sandy loam; $22-50 \mathrm{~cm}$, light brown sandy loam; $50-53 \mathrm{~cm}$, reddish-brown sandy loam. 200+ pea-sized IOG. 0-20 cm, 2 sherds; $20-40 \mathrm{~cm}, 2$ sherds.

ST $10 \quad 0-10 \mathrm{~cm}$, dark brown gravelly loam; $10-28 \mathrm{~cm}$, light reddish-brown gravelly loam; $28 \mathrm{~cm}+$, red clay. $200+$ pea-sized IOG. $0-20 \mathrm{~cm}, 1$ sherd.

ST 11 0-25 cm, reddish-brown sandy loam; $25-35 \mathrm{~cm}$, light reddish-brown sandy loam; $35 \mathrm{~cm}+$, red clay. $200+$ pea-sized IOG. $0-20 \mathrm{~cm}, 1$ sherd.

ST 12 0-30 cm, dark brown sandy loam; 30-43 cm, light reddish-brown sandy loam; 43$46 \mathrm{~cm}+$, red clay. $200+$ pea-sized IOG. $0-20 \mathrm{~cm}, 1$ sherd. 


\section{Appendix 2, OCR Dating Forms}




\section{Calculated OCR DATE Report}

For TAS

13-Dec-00

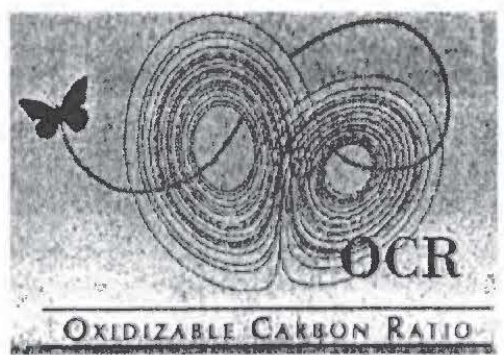

\begin{tabular}{|r|r|r|}
\hline Sample Id: & ACT \# 4892 \\
\hline Site Id \#: & Location: & UNIT 1 \\
\hline Feature Type: & Cultural \\
\hline Feature Designation: & $11 / 16 / 00$ \\
\hline Sample Recieved: & 273 & \\
\hline Calculated OCR DATE: & YBP(1950) & $+1-8$ \\
\hline
\end{tabular}

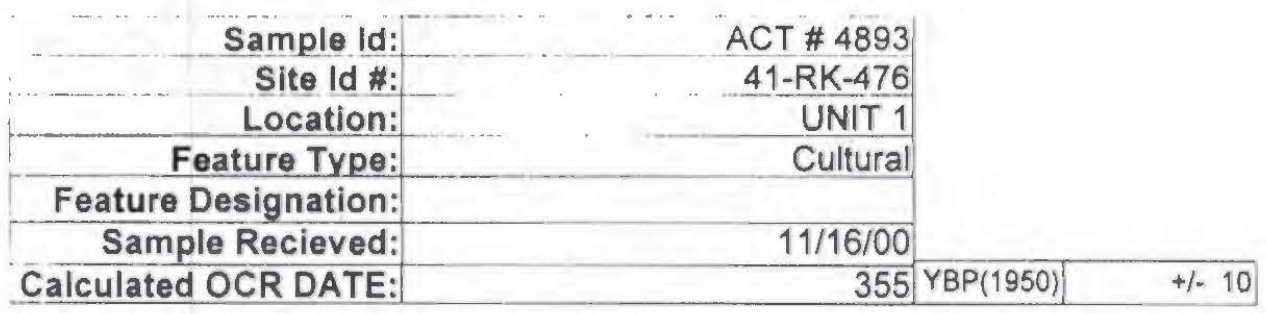

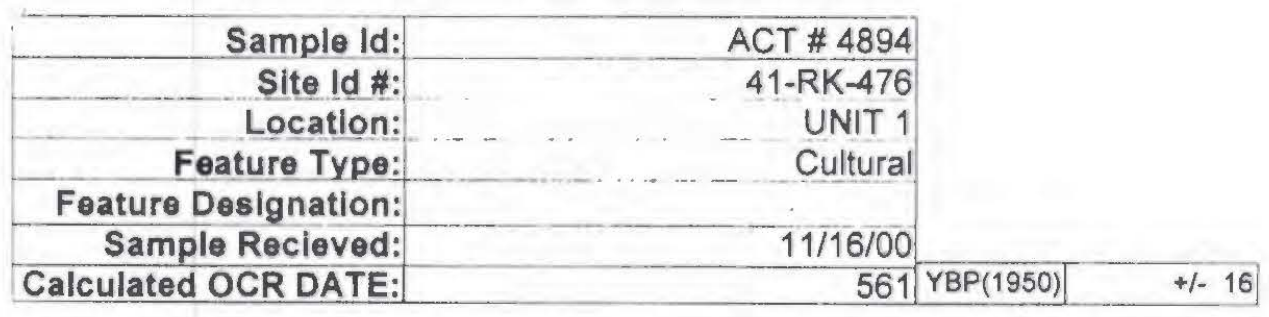

\begin{tabular}{|r|r|}
\hline Sample Id: & ACT \# 4895 \\
\hline Site Id \#: & $41-$ RK-476 \\
\hline Location: & UNIT 1 \\
\hline Feature Type: & Cultural \\
\hline Feature Designation: & $11 / 16 / 00$ \\
\hline Sample Recieved: & 700 \\
\hline Calculated OCR DATE: & YBP $(1950)$ \\
\hline
\end{tabular}




\section{Calculated OCR DATE Report}

\section{For TAS}

\section{3-Dec-00}

\begin{tabular}{|c|c|c|c|}
\hline Sample Id: & ACT \#4896 & & \\
\hline Site Id \#: & $41-R K-476$ & & \\
\hline Location: & UNIT 1 & & \\
\hline Feature Type: & Cultural & & \\
\hline \multicolumn{4}{|l|}{ Feature Designation: } \\
\hline Sample Recieved: & $11 / 16 / 00$ & & \\
\hline Calculated OCR DATE: & 806 & YBP(1950) & $+/-24$ \\
\hline
\end{tabular}

\begin{tabular}{|r|r|}
\hline Sample Id: & ACT \# 4897 \\
\hline Site Id \#: & $41-\mathrm{RK}-476$ \\
\hline Location: & UNIT 1 \\
\hline Feature Type: & Cultural \\
\hline Feature Designation: & $11 / 16 / 00$ \\
\hline Sample Recleved: & 964 \\
\hline Calculated OCR DATE: & YBP $(1950)$ \\
\hline
\end{tabular}

\begin{tabular}{|r|r|}
\hline Sample Id: & ACT \# 4898 \\
\hline Site Id \#: & $41-R K-476$ \\
\hline Location: & UNIT 1 \\
\hline Feature Type: & Cultural \\
\hline Feature Designation: & $11 / 16 / 00$ \\
\hline Sample Recieved: & 1091 \\
\hline Calculated OCR DATE: & \\
\hline
\end{tabular}

